\title{
Cuba ved en korsvej
}

\section{Jens Lohmann}

\section{0 år efter revolutionens sejr er det cubanske styre i alvorlig eksistentiel krise - som næppe kan klares med central styring og fortsat undertrykkelse af kritikere}

De officielle festligheder i anledning af 50-året for den cubanske revolutions sejr og Fidel Castros overtagelse af magten i Cuba i januar 1959 er overstået, og tømmermændene og de nødvendige refleksioner har meldt sig (igen) hos cubanerne og landets ledelse med lillebror Raúl Castro i spidsen og den aldrende leder Fidel i baggrunden. De mange smukke ord i festtalerne kan nemlig ikke skjule, at den cubanske revolution er i dyb krise, og at der skal radikal fornyelse til, hvis landet skal komme ud af hullet.

Det er alt for forenklet at sige, at revolutionen er en fiasko, som dens modstandere hævder, eller en succes, som styret og dets støtter påstår. Billedet er langt mere komplekst og løsningen er næppe den klassiske nyliberalistiske opskrift, hvis bagside vi efter flere års økonomisk opgang nu oplever for fuld udblæsning. $\mathrm{Og}$ som ikke mindst de latinamerikan- ske lande har mærket i årtier.

De skæggede revolutionære, los barbudos, som 1. januar 1959 jog den USA-støttede diktator Fulgencio Batista på flugt, repræsenterede et håb om demokrati, social retfærdighed og fornyelse i et dybt korrumperet samfund med store sociale skel.

\section{De skæggedes eksperimenter}

De ønskede at gennemføre dybe forandringer i det cubanske samfund. Deres idealer fejlede intet. Men de var for størstepartens vedkommende unge og uerfarne. Fejltagelserne og overgrebene blev mange. Revolutionen blev målet over alt, den kunne og måtte ikke anfægtes. "Inden for revolutionen er alt tilladt, udenfor intet", sagde Fidel Castro til kunstnere og intellektuelle på et seminar i 1961. På det tidspunkt befandt landet sig stadig i en slags revolutionær eufori, men også i en belejringstil- 
stand efter den mislykkede CIA-organiserede invasion i Svinebugten i april 1961.

De unge ledere var søgende. De nåede frem til at socialisme var vejen til et bedre samfund. Men ikke en betonsovjetisk udgave. Så de søgte svar $i$ alle retninger og indbød i løbet af 1960'erne venstreorienterede teoretikere og praktikere af forskellig observans til diskussioner, lyttede, plukkede noget her, noget dér. De eksperimenterede med økonomien. Men når toppen havde truffet en beslutning, stod den ved magt. Den kunne ikke anfægtes.

Det kom til at koste dyrt - det åbne og frie rum, som havde præget den politiske og kulturelle diskussion de første år, blev gradvist indsnævret. USA's aggressive politik over for og blokade af den lille rebelske østat, som man hidtil havde betragtet som et appendiks til USA, blev en central retfærdiggørelse for de stadige stramninger, der nåede et foreløbigt højdepunkt med den 'revolutionære offensiv' i 1968, hvor al privat $\varnothing$ konomisk aktivitet blev lagt ind under staten, bortset fra de statskontrollerede landbrugskooperativer.

Med Fidel Castros støtte til Warszawapagt-invasionen af Tjekkoslovakiet $i$ august 1968 og den efterfølgende lukning af partiskolerne hvor den politiske debat var særlig dybtgående - var revolutionen nået til en slags konsolidering, hvor afhængigheden af Sovjetunionen de følgende år i vidt omfang blev styrende for den kurs man lagde.

\section{Låst fast under Sovjetunionen}

Cuba blev medlem af den Sovjetstyrede, østlige økonomiske sammenslutning COMECON, hvor de enkelte landes økonomi blev indrettet og styret efter overordnede retningslinjer, som fastholdt landene i bestemte økonomiske roller. Cuba fik tildelt rollen som leverandør af sukker, sydfrugter og nikkel, mens olie, maskiner, transportudstyr og andre industrivarer blev leveret fra de andre lande. Eksperimenternes tid var forbi. Cubas økonomi blev indrettet og planlagt efter sovjetisk/østeuropæisk mønster uden at tage megen højde for landets særlige forhold og forudsætninger.

Kritik blev betragtet som forræderi og straffet med hårde fængselsstraffe. Sagen mod digteren Heberto Padilla, der i 1970 blev anklaget for at være kontrarevolutionær på grund af den tvetydige ordlyd i en præmieret digtsamling, var med til at bryde omverdenens betagelse af Cuba som et frit og fornyende alternativ til de etablerede kommunistiske regimer.

Landet blev et gennemkontrolleret, stærkt centralstyret samfund, som i 1970'erne var ret isoleret fra den vestlige verden. Til gengæld lykkedes det gennem en dygtig diplomatisk indsats gradvist at skabe Cuba en position blandt landene i 
Afrika og dele af Asien. Billedet af den cubanske David over for den amerikanske Goliat skabte sympati. Desuden kunne Cuba fremvise store fremskridt inden for centrale områder som uddannelse, sundhed og social sikring på trods af de vanskelige vilkår fremkaldt af en stiv, centralistisk økonomi, hvis negative følger blev forstærket af den amerikanske blokade.

Efter den mislykkede sukkerrørshøst i 1970, som tappede de fleste ressourcer i forsøget på at nå rekordmålet 10 millioner ton sukker, begyndte en stabil økonomisk fremgang, der varede frem til 1985. Omkring 1980 kunne cubanerne endelig begynde at mærke en vis økonomisk fremgang og forbedringer i de materielle levevilkår. Det politiske greb blev slækket en smule, og forbindelserne til omverdenen blev forbedret - dog ikke til USA, som efter Ronald Reagans tiltræden i 1981 holdt fast $i$, at det cubanske styre skulle kvæles og knuses.

\section{Den specielle periode}

Men da Mikhail Gorbatjov blev Sovjetunionens leder i 1985, betød det en ende på fremgangen. Gorbatjov ændrede vilkårene for den sovjetiske støtte til Cuba, hvor økonomien begyndte at stagnere. Da Berlinmuren faldt, og Sovjetunionen og Østblokken brød sammen i 1989-91 betød det en af de alvorligste kriser i Cubas historie. Den sovjetiske olie skulle betales til markedspriser, og cubanske varer skulle konkurrere på et internationalt marked, hvor de ikke var særlig konkurrencedygtige. I årene 1990-93 faldt Cubas BNP med hele 33 pct.

Det indledte den såkaldte Período Especial, specialperiode, der i øvrigt ikke er erklæret for afsluttet endnu. De værste år i 1990'erne betød alvorlig mangel på næsten alt og et endnu alvorligere forfald af produktionsapparatet, end hvad man hidtil havde kendt. Næsten alle maskiner i Cuba er importerede og der var ikke valuta til at importere reservedele eller nye maskiner efter, at subsidierne fra Østblokken og Sovjet var bortfaldet. Landbrugets maskiner stod stille, og forhåndenværende husdyr som køer og heste blev brugt som trækkraft.

Forsyningerne af fødevarer til byerne blev dårligere, end de var i forvejen. Mens folk i byerne fortvivlet søgte at skaffe mad, kunne tonsvis af frugt og grøntsager ligge og rådne på markederne fordi der ingen transport var - enten på grund af manglende reservedele, på grund af dårlig planlægning, eller fordi private ikke måtte transportere fødevarer ind til byerne i salgsøjemed.

Siden 2000 er det igen gået frem$\mathrm{ad}$, men først i 2005 nåede $\mathrm{BNP}$ op på 1989-niveauet - og vanskelighederne er langtfra overvundet. Blandt andet er infrastrukturen stærkt nedslidt - gader og veje, jernbaner, kloakker, vand- og elforsy- 
ning, telefonnettet - efter årtiers forsømmelser.

\section{Raúls små skridt}

Det store spørgsmål er, hvad det cubanske styre kan og vil gøre for at komme ud af hullet. Der er ingen tvivl om at der er brug for alvorlige indgreb, hvis landet skal undgå omfattende social uro. Utilfredsheden blandt cubanerne er voksende, selv om Raúl Castro efter sin tiltrædelse i februar 2008 som sin storebrors afløser et par måneder senere tillod cubanerne frit at købe computere, mobiltelefoner, hårde hvidevarer, motorcykler og andre forbrugsgoder, samt at bo på hoteller, der hidtil havde været reserveret udenlandske turister.

Desuden blev der åbnet for at private bønder kan forpagte jord - meget af det er den brakjord, der ligger efter reduktionen i dyrkningen af sukkerrør. Restriktionerne på rejser blev lempet, og det blev lettere at få tilladelse til at handle med biler og huse. Alle køb skal dog betales i konvertible pesos, CUC, der svarer til dollar (dollar er ikke tilladt som betalingsmiddel, men skal veksles til CUC), og der er siden indført en række restriktioner.

Der er to valutaer i Cuba, CUC og den almindelige peso, som der går 25 af på en CUC. Den cubanske økonom Oscar Espinosa Chepe, der har været fængslet som dissident, oplyser på grundlag af officielle tal, at cubanernes gennemsnitsmånedsløn i 2007 var 408 pesos (ca. 16 CUC), og at realmånedslønnen i 2006 var på 45 1989-pesos, et fald på 76 pct. på 17 år.

Revolutionen i 1959 fik en drastisk indflydelse på indkomstfordelingen. Den svenske økonom og Cubakender Claes Brundenius peger på at især landbrugsreformen og boligreformen, som blev iværksat i 1959 og 1960 fik en voldsom effekt på indkomstfordelingen. I 1962 var gini-koefficienten faldet til 0,32 fra 0,55 i 1953 - jo lavere gini-koefficient, des jævnere indkomstfordeling. Man kunne så tilføje, at mange af de mest velstående cubanere flygtede fra landet i revolutionens første år. Men tendensen fortsatte indtil slutningen af 1980'erne. I 1978 beregnedes Gini-koefficienten til 0,25 og i 1986 til 0,22, det vil sige, at indkomstfordelingen nåede et nordisk niveau. Siden er det imidlertid gået den anden vej til 0,38 i 2005. Stadig lidt bedre end i resten af Latinamerika, men intet tyder på, at tendensen vender.

\section{Tabere og vindere}

Det samme billede ses, hvis man kigger på indkomstfordelingen. I 1953 modtog de fattigste 40 pct. af befolkningen 6,5 pct. af den samlede indkomst, det samme niveau som i det meste af Latinamerika. I 1962 var andelen vokset til 17,2 pct., i 1978 24,8 pct. og i 198626,0 pct. I slut- 
ningen af 1980 'erne vendte billedet igen. I 1989 var de fattigste 40 procents andel af den samlede indkomst faldet til 23,3 pct., i 1996 til 13,9 pct. og i 1999 til 12,5 pct.

Ifølge Brundenius er taberne især pensionister uden andre indtægter end deres pension, arbejdsløse med understøttelsen som eneste indtægt, syge og folk på barsel, lønarbejdere i mindre virksomheder, sundhedspersonale og lærere, det vil sige folk med indtægter kun i almindelige pesos. Mens vinderne er de som modtager penge fra familie i udlandet, ansatte i turistsektoren, private landbrugere og andre selverhvervende, samt ansatte i nye sektorer, bl.a. joint ventures med udenlandske firmaer inden for energi, telekommunikation og bioteknologi.

Det er med til at overskygge revolutionens successer, specielt inden for sundhed og uddannelse, der må betegnes som sande succeshistorier.

I 1959 var der 7000 læger i landet. En tredjedel af dem forlod landet de følgende år. Det var en katastrofe for det nye styre, der havde sundhed for alle som et af sine vigtigste mål. Selv om man satsede hårdt, tog det næsten 15 år at komme op på samme antal som før revolutionen.

Man kompenserede dog med uddannelse af andet sundhedspersonale og oprettelse af sundhedscentre helt ud i de fjerneste afkroge. I 2007 havde Cuba 72.416 læger, gratis lægehjælp og hospitaler til alle. Børnedødeligheden er bragt ned fra
37,7 per 1000 i 1960 til 5,3 i 2007.

Men krisen slår også til her. Selv om Cuba er blevet et af verdens førende lande inden for sundhed og pionér inden for bioteknologi, betyder den amerikanske blokade og manglen på valuta, at det er dyrt og svært at skaffe medicin og udstyr.

Revolutionen har betydet, at cubanerne er det bedst uddannede folk $\mathrm{i}$ Latinamerika. Uddannelse på alle niveauer er gratis, og adgangen til højere uddannelser er lettet ved oprettelsen af universitetsafdelinger $\mathrm{i}$ alle landets kommuner. I undervisningsåret 2007-2008 var der indskrevet 744.000 studerende på videregående uddannelser - ud af en befolkning på 11,5 mio. Det er imponerende.

Men den langvarige krise har betydet nedslidte bygninger og mangel på tidssvarende udstyr. Og i en alvorlig økonomisk krisesituation, hvor mange akademikere ikke kan få job, hvor mange må klare sig med forhåndenværende småjobs og finde beskæftigelse i den uformelle sektor (hvor meget er forbudt), simrer en utilfredshed, der nemt kan udvikle sig til noget større.

\section{Spændt tålmodighed}

Cubanerne er trætte af løfter og undertrykkelse. Selv om mange er stolte over revolutionen, der har forbedret mange ting og bragt landet på verdenskortet, er tålmodigheden med forholdene og styret efterhån- 
den på bristepunktet. Raúl Castros overtagelse af landets ledelse efter storebror Fidel i 2008 bragte fornyet håb, som blev næret af indførelsen af enkelte reformer.

Men resultaterne lader vente på sig. Folk vil se resultater her og nu. For eksempel at kunne købe mad nok uden at skulle stå i lange køer for at få det der tilkommer en til lave priser efter rationeringsbogen. Fødevareforsyningerne er et grotesk kapitel i et frugtbart land, som den franske agronom og udviklingsekspert René Dumont i 1960 mente kunne brødføde 50 mio. mennesker, og som i dag importerer 80 pct. af sine fødevarer - bl.a. fra USA.

For den almindelige cubaner er det nærmest en hån at vide, at der kan ligge tonsvis af høstede landbrugsafgrøder og rådne på de selvstændige bønders marker, fordi der er stærke restriktioner på den private handel, og fordi der ofte ikke er mulighed for at transportere varerne til markederne i byen.

Kører man på landet i Cuba, kan man se nedslidte lastbiler og traktorer holde stille, fordi der ikke er reservedele eller fordi de simpelthen ikke kan mere. De store, ineffektive statsbrug råder over nyere køretøjer, men de må ikke anvendes til transport af varer fra de private brug.

Har man penge kan man få. Dels i de statsdrevne supermarkeder og indkøbscentre, hvor man skal betale med CUC, dels gennem private forbindelser, som skaffer alt fra friske tomater til nyfangede hummere (de sidste er ellers forbeholdt de statsejede restauranter og hoteller). En omfattende undergrundsøkonomi holder gang i meget - men mange er holdt udenfor, nemlig de mange, som ikke råder over den hårde valuta. Og staten har ingen styring over denne voksende sektor og mister samtidig indtægter.

\section{Forbereder sig på uro}

Blandt de omlægninger den nye ledelse har sat i gang, er en omorganisering af politiet. Officielt er det for at komme småkriminalitet og korruption i korpset til livs. At det findes i politiet er ingen overraskelse. Politiet er hårdhændet og ikke videre populært, så det er sikkert populært at politiet bliver udrenset.

Men der kan være en anden, dybereliggende hensigt, nemlig at forberede politiet på at skulle gribe ind mod uro og demonstrationer. Der har allerede været smådemonstrationer, stenkast mod busser, det meste af det formentlig spontant. Men det kan brede sig i takt med at krisen bliver værre. Og så vil taler med løfter om nye reformer, udskiftning af ministre og enkelte $\varnothing$ konomiske indgreb næppe være nok.

Det haster for Raúl Castro og hans nye hold af ministre og embedsmænd at fremvise konkrete resultater. De spæde forsøg på en ny landbrugsreform er ikke tilstrækkelige, hvis hurtige og tilstrækkelige fødeva- 


\section{JENS LOHMANN}

reforsyninger skal sikres. Der er brug for beskæftigelse - og der er nok at tage fat i med fornyelsen og udbygningen af den nedslidte infrastruktur. Det er styrets tydelige hensigt at tiltrække udenlandske investeringer. Men det er ikke nok at have en veluddannet befolkning, hvis infrastrukturen ikke fungerer og hvis der er social uro. Så bliver investorerne borte.

Hvis styret mener det alvorligt med forandringer, bliver det nødt til også at foretage en politisk åbning og tillade en opposition og kritik af sin politik. Cuba er et af de mest undertrykte lande i verden. Mange af de ca. 200 politiske fanger afsoner hårde fængselsstraffe under stærkt umenneskelige forhold. Selv om USA og EU har blødt op over for Cuba efter Barack Obamas tiltræden, kan styret næppe forvente megen forståelse for en fortsat under- trykkelsespolitik. Det er endnu uklart, hvilken vej Raúl Castro og hans hold vil følge. Den hidtidige kurs har spillet fallit. Det har dens nyliberale modstykke også. Er der en farbar tredje eller fjerde vej, hvor økonomisk og social fremgang kan skabes under demokratiske forhold i et land som Cuba? Især i en krisetid, hvor også Cubas økonomi bliver hårdt ramt - de tre vigtigste valutaindtægtskilder, turismen, nikkeleksporten og pengeforsendelserne fra slægtninge i udlandet, er allerede faldet kraftigt, og vil formentlig falde endnu mere.

Det er et kapløb med tiden for Cubas ledere at finde og vælge en vej ud af moradset. Cuba står ved en korsvej. Quo Vadis, Cuba?

Jens Lohmann er journalist og forfatter specialiseret i latinamerikanske forhold. 


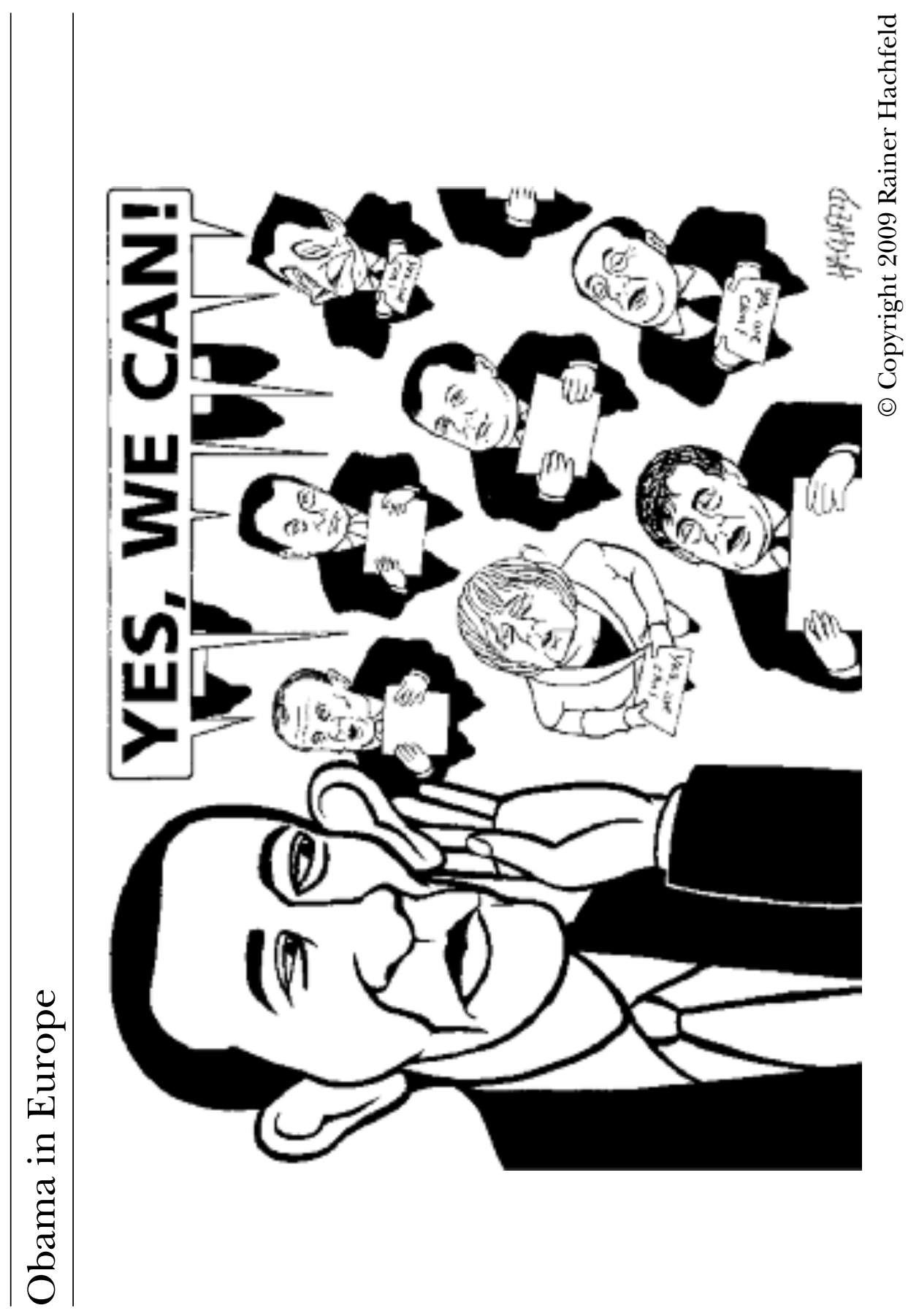

udenrigs 1 • 2009 